\begin{abstract}
Utilizing theories of identity this article presents findings from a qualitative study regarding the significant role independent franchisee associations play within franchise systems. The data reveal that successful franchisee associations help manage the inherent tension that exists between cooperation and conflict in franchise relationships. A distinctive adaptive organizational identity provides an association the capability necessary to reframe its relationship with the franchisor as either combative or cooperative in response to changes in a franchisor's identity. Challenging the views of both franchisor stability and the dyadic form that franchisee-franchisor relationships assume, behavioral insight is provided into the actual functioning of franchise systems and new avenues are suggested for theory building in franchising.
\end{abstract}




\section{Identity in Franchise Systems: The Role of Franchisee Associations}

"For the younger generation, of which I am a part, we must not take for granted 'The Hard Way' that our forefathers endured for this brand. They took the high road and worked arduously to pour a solid foundation so that the brand could be sustained. This foundation took years to perfect and must be maintained to preserve our heritage, our rights and our future. It is our responsibility and obligation to understand our heritage and our rights so that we may continue this great brand that the Colonel himself entrusted to us. We are a family, and I think you will see that reiterated throughout every page in this historical reflection. Family is what brought me to KFC and the AKFCF, and I have so many extended family members because of this affiliation.” Michelle Hunt - Editor AKFCF Quarterly (The KFC Franchisee Association Newsletter)

The statement above from the KFC franchisee association newsletter highlights an organization that has real impact on the lived experiences of franchisees and the systems in which they operate but has been largely ignored in franchising research - the independent franchisee association. Although relationships among franchisees, have been found to influence franchisee attitudes and behavior (Kalnins and Chung 2006; Dickey 2003) franchising researchers have just begun to acknowledge the existence of formal organizational structures that embody such relations (see Cochet and Ehrmann 2007; Lawrence and Kaufmann 2010 for examples). Several researchers have recognized the potential countervailing power of these structures (i.e. Grünhagen and Mittelstaedt 2002; Argyres and Liebeskind 1999; Carney and Gedajlovic 1991), but none have examined how these associations actually function within franchise systems.

This lack of research is surprising because independent franchisee associations have emerged as important, influential and prolific structures within modern franchise systems and have aroused a great deal of interest among practicing franchise lawyers (e.g., Barkoff and Green-Kelly 2006; Spandorf and Barkoff 2003; Selden 2000; Burzych, Karp, and Satterliee 2004). Moreover, as confirmed via the authors' research all but eight of the top 20 largest franchise systems have currently active independent franchisee associations. Of the remaining 
eight McDonalds, Ace Hardware, Marriott, Hilton, Re/Max, Coldwell Banker, and Health Mart all have some kind of advisory councils comprised of franchisees. Furthermore, the Federal Trade Commission has recognized the potential influence of franchisee associations and as of July 1, 2008 amended its Franchise Rule mandating explicit disclosures in each system’s Franchise Disclosure Document (FDD) of the existence of any independent association (or alternative form of franchisee group) requesting such recognition. Just as initial explanations of franchising based on the assumption of single-unit franchising failed to consider the growth and impact of multi-unit franchising (Kaufmann 1996; Kaufmann and Dant 1996), the general assumption that solitary franchisees act alone in dyadic relations with the franchisor ignores the complexity of inter-franchisee relations as they operate today.

For the past 40 years, franchise research has been dominated by two such approaches 1) a focus on the structural characteristics of the franchise form and 2) an examination of the link between psychological traits of franchisees and their attitudes and behavior. Economic theories explaining franchising and the resultant structures of franchise systems enjoy a well deserved prominence in the literature (see Blair and Lafontaine 2005). The primary focus of that approach has been on understanding the incentives that achieve optimal efficiency within the franchise system (Rubin 1978; Brickley and Dark 1987). However, the only relationship of interest is that between franchisor and franchisee and both parties are assumed to be context free economic actors. The second approach has been to examine the psychological traits of franchisees and link those traits to attitudes including satisfaction (Hing 1995; Morrison 1997) and behaviors (Jambulingam and Nevin 1999). Again, the only examined relationship is between franchisor and franchisee, and franchisees are assumed to be individual psychological actors. Neither approach recognizes any social context or formal organization in which inter-franchisee 
relationships are enacted. With few exceptions the scope of franchising research has been limited to this dyadic model. Formalized inter-franchisee relationships and the potential of such groups in mediating the relationship between individual franchisees and the franchisor have not been considered as important components or influencers in the franchise system.

Each franchise system is comprised of two distinct legal entities, the franchisee and franchisor, who although they are members of a single superorganization (Reve and Stern 1979) have both shared and competing goals. As the often used tagline of franchising, "work for yourself, not by yourself” illustrates, franchising agreements create a unique relationship between franchisor and franchisee. To outsiders the franchisee may resemble a quasi-employee of the firm and has been characterized as giving up his or her own identity to assume the identity of the franchisor (Caves and Murphy 1976). However, unlike an employee working within an authority based hierarchy, franchisees are legally independent contractors that typically view themselves as equal partners with the franchisor. The franchisee association resides within this complex superorganization and provides a way for these independent contractors to interact collectively with the franchisor.

The interdependent relationship between franchisor and franchisees creates significant managerial challenges for both franchisee association leadership and franchise system corporate management as franchisee based organizations enact their unique, collective identity within franchise systems in somewhat the same way that unionized employees do within wholly owned firms. Collaborative relationships between system management and franchisee associations may lead to greater system wide efficiencies. However, associations that focus attention on their collaborative work with the franchisor and on accomplishing collective goals may be unable to control member perceptions of co-optation and fail to maintain their identity as legitimate 
autonomous bodies. Conversely, the countervailing power (Galbraith 1954) afforded such associations and the potential for adversarial relationships arising from in-group/out-group distinctions are a potentially powerful uniting force for franchisees looking to assert their role as autonomous agents. As such, franchisee associations can consciously fortify the identity disparity between franchisee and franchisor, building solidarity among their members by highlighting an adversarial combative relationship. When franchisee associations fail to temper this bias however, conflict between franchisor and franchisee may spiral out of control and destroy any hope for working together for the good of the system.

In examining the management of these franchisee associations, we seek to understand the role organizational identity plays in their maintenance. Because some independent franchisee associations endure while others fail, we ask the following questions: what characteristics give rise, and sustenance, to these organizations and how do these organizations manage the inherent tension between cooperation and conflict? Our data suggest that an adaptive association identity interacts with the perceived instability of franchisor identity to provide the critical factors determining their continued existence. In order to survive, franchisee associations, like labor unions, must strike the balance between cooperative and combative behavior (Hammer and Stern 1986) to assert both their autonomy and interdependence vis-à-vis the franchisor. Such shifts in identity accomplish the dual task of maintaining solidarity and control among their membership while also working constructively with their franchisor management team to foster efficient system operation and enact change when necessary. The purpose of this paper is to develop a theoretical framework to understand such identity dynamics at work within franchising. We propose that the creation and maintenance of an adaptive identity enables associations to react to changes in a franchisor's corporate identity, facilitating cooperative behavior with the franchisor 
while also working to temper the in-group/out-group bias that, while enhancing franchisee solidarity, threatens continued franchisee-franchisor collaboration.

Utilizing theories of organizational identity to help interpret our findings in the field we work towards an emic understanding of the functioning of these independent franchisee associations. In doing so, we address the call for research that takes a phenomenological approach to the development of theory that challenges prior conceptualizations of franchising (Dant 2008). First we briefly review the relevant theory and describe the features of franchisee associations. Then in the sections that follow, we use qualitative data to inductively build our conceptualization of a dynamic association identity around three key insights; 1) identity (in)stability (on the part of both franchisee and franchisor) as a key variable in understanding the functioning of franchisee associations, 2) the necessity of an adaptive association identity to temper intergroup bias and foster cooperation while maintaining solidarity among members and 3) the capability for such adaptation rooted in traditions, rituals and artifacts, free spaces, franchisee stability, democratic governance and financial resources. We then discuss our findings as they relate to the potential for further theory development on identity in franchising.

\section{Organizational Identity}

Organizational identity helps members of an organization answer the question "Who are we?” (Albert, Ashforth, and Dutton 2000), by describing what is central, distinctive and enduring about the organization (Albert and Whetten 1985). Just as the perception of one's self is constructed through both membership in, and separation from, particular groups (Tajfel and Turner 1979; Ashforth and Mael 1989), an organization also constructs its identity through such a comparative process. The organization, situated in its broader environment, answers the question "who are we?” in part by answering the question “who are they?”, i.e., by comparing its 
own identity with the perceived organizational identity of other groups in its environment. This reflexive iterative process of interaction with other groups helps to construct and update a group’s distinctive identity.

Within a typical franchise system, there are multiple sub-organizations, each with its own identity. For example, the franchisor (as distinct here from the overall franchise system) is itself an organization comprised of those individuals who currently own and manage the overall system. Because our focus in this paper is on the organizational identity of the franchisee association, other organizations both outside and within a franchise system (including the franchisor organization) are important because they form the environment that helps define the focal franchisee association’s identity. For our purposes, therefore, the franchisor organization’s identity is defined in terms of how outside constituents (including the franchisee association) view that organization not the way that members of the franchisor organization (i.e., those individuals running the franchisor corporation) might view it themselves. To highlight this distinction we use the term franchisor's corporate identity to refer to the organizational identity of the current franchisor ownership and management team as perceived by franchisees and the franchisee association (this definition follows corporate identity as defined by Bhattacharya and Sen 2003).

Changes in an organization's environment, including changes in the identity of key stakeholders (i.e. the corporate identity of the franchisor for franchisee based groups), may become incongruent with the organization's current identity requiring the organization to adapt its identity in order to survive (Gioia, Schultz, and Corley 2000; Scott and Lane 2000). Though organizational identity described by Albert and Whetten (1985) is defined as the collective understanding of that which is central, distinctive and enduring about the organization, an 
appreciation that identity is somewhat adaptive and changeable over time (Albert and Whetten 1985; Dutton and Dukerich 1991; Brown and Starkey 2000) introduces a paradox-- that organizational identity is both fluid and stable. The paradox is addressed by the work of Gioa et al. (2000) who describe organizational identity as dynamically adaptive and differentiate between an enduring identity and one with continuity. An enduring identity, one that remains the same over time with permanency, is conceptually problematic in light of changes in environmental conditions that require an organization to adapt (Gioa et al. 2000). On the other hand, an identity that is continuous retains labels and values over time while shifts in the interpretation and meaning of those labels allow for adaptation to dynamic environmental conditions (Gioa et al. 2000). In other words, though certain labels given to the identity may remain stable (e.g., upholding the values of the founder and thinking of ourselves as a family, see the opening quote), the meaning ascribed to those labels (i.e. what it means to be a family member or to uphold the values of the founder) can change over time. In this paper we adopt Gioa et al.’s (2000) dynamic view of organizational identity and argue that it is specifically this adaptive capability that enables the survival of franchisee associations in the long term.

Franchising is a particularly interesting context to study the management of organizational identity, as franchisees are neither full time employees nor independent entrepreneurs. Like contract workers (George and Chattopadhyay 2005) or union members (Fullagar and Barling 1991) they have multiple, sometimes competing, work groups with which to identify. Even though the loss of individual identity has been defined as a hallmark of the franchise relationship (Coughlan et al. 2006, 518) research exploring identity theory in a franchising context has been limited (for exceptions see Ullrich et al. 2007; Rometsch and Sydow 2006). Ullrich et al. (2007) examined franchisee employee's identification with 
both their immediate work group at the franchisee level (lower order categorization) and with the franchisor (higher order categorization). They found that workgroup identification predicts customer-orientated behavior while franchisor identification predicts corporate citizenship behavior. Romestch and Sydow (2006) have examined the process of constituting identity in a case study of a German McDonald's franchise system. They conclude that the lack of social space for creating a distinct German organizational identity results in the dominance of the overall McDonald's identity. They do suggest that franchisee based groups and conferences may provide avenues for independent franchisee organizational identity to emerge and propose that future work examine this process of identity construction. Though both studies acknowledge franchising as a potentially fruitful context for developing theory regarding identity; neither investigates the unique identity processes inherent in the formation or maintenance of franchisee based groups.

\section{Franchisee Associations}

As noted above, almost all mature systems have some sort of franchisee based organization. These organizations can be arrayed along a continuum from entities that are totally franchisor funded and supported (often referred to as franchisee advisory councils - or FACs), to franchisee created and supported structures (often referred to as independent franchisee associations - or IndFAs), to ad hoc groups created for the simple purpose of litigation. FACs are typically comprised of franchisor appointed or elected franchisees and play a formal communication role within the system. Although ostensibly designed to represent franchisee interests, FACs are often unidirectional communication devices through which the franchisor speaks to its franchisees, and are typically seen as lacking sufficient authority or 
power to demand change. ${ }^{1}$ Anchoring the other end of the continuum are groups of franchisees temporarily bound together solely to pursue legal action against the franchisor. Spanning the middle of the continuum and at times containing elements of both extremes are IndFAs. These associations may not be sanctioned or even recognized by the franchisor and many coexist and share members with litigation groups and franchisor controlled FACs operating within the same system. The governance of IndFAs is usually completely free of input from the franchisor and officers are typically elected from the membership of the IndFA or may include professionals hired by the IndFA. This research focuses on associations that label themselves as IndFAs and when we refer to an association we are referring to this type of group unless otherwise specified.

\section{METHODOLOGY AND DATA}

Three sources of data were used in constructing this analysis, secondary data available via mass media channels and from association websites and literature, participant observation at franchisee association conferences, and unstructured interviews with those with experience with franchisee associations. The investigation began with an analysis of franchisee association websites, joining, engaging and reading franchisee web forums and attending regional franchising group events. These sources along with mass media articles, franchisee association newsletters and law articles about franchisee associations provided a knowledge base prior to the first author's immersion in the field. The first author participated in three unique franchisee association conferences. The first conference, spanning four days, was a national gathering of

\footnotetext{
${ }^{1}$ A quote from franchisee.org the website for the AAFD, the leading advocacy group for franchisee associations, states: "A franchisee association is an independent organization of franchisees. It is distinguished from advisory councils or other entities sponsored or funded by the franchisor. Some associations have been funded by the franchisor, but the resulting inhibition of independent action on behalf of franchisee interests makes such organizations at best a hybrid, and at worst completely compromised in their ability to represent franchisee interests"
} 
franchisee association leaders and advocates representing dozens of American franchise systems. Two subsequent conferences, spanning four days and five days respectively, were specific annual conferences of two of the largest franchisee associations in the United States. Prior to the conferences, the focal association's newsletters and websites were analyzed to provide a broad understanding of the structural characteristics of these associations and the key players within them. During the conferences, the first author attended dinners, awards ceremonies, board meetings, town hall meetings, franchisor presentations and social gatherings to engage franchisees in their natural surroundings. In addition to the 34 recorded interviews described below, informal discussions with dozens of franchisees during said conferences helped to inform this research. Field notes were taken and theoretical memos written to illuminate key findings from the field and to isolate variables of interest. The second author, though an academic, is a current, active franchisee association board member in a large American franchise system. While data from the specific system in which the second author is involved was not used in this research, that author's role on an association board provided valuable insight that aided in both the selection of interview subjects and in the interpretation of the data.

Utilizing our knowledge base we purposively sampled (Patton 2001) individuals with experience in 19 unique associations in a range of systems in various stages of maturity and representing a wide variety of sectors (Table 1). Though interviews were unstructured, questions were based around several main themes: descriptive detail of the association and its history including the individual's participation with the system, membership within the association, and relationships between franchisees, between franchisee association and franchisor, and between franchisee and franchisor. This approach permitted an open dialogue between researcher and interviewee allowing interesting avenues of insight to emerge. Most interviewees had extensive 
history within the focal system with an average of 21 years $(\sigma=10)$ years of experience and collectively 719 years of experience with franchising. Interviewees included 16 former and current association presidents/directors and ten former and current board members (See

Appendix 1 for full list). Due to the sensitive nature of the discussions all informants have been given aliases and data that would identify the informant has been slightly modified.

\section{Table 1: List of Franchise Systems}

\begin{tabular}{|l|l|l|}
\hline Franchise System & Association & $\begin{array}{l}2009 \text { US } \\
\text { Franchisees }\end{array}$ \\
\hline 7-Eleven & National Coalition of Associations of 7-Eleven Franchisees & 5622 \\
\hline Candy Bouquet & Candy Bouquet (AAFD Chapter) & 485 \\
\hline Cookies by Design & The Cookies by Design Franchisee Association (AAFD Chapter) & 179 \\
\hline Curves & Curves Franchisee Association & 6329 \\
\hline Children's Orchard & The Children's Orchard Cooperative & $58^{* *}$ \\
\hline Domino's & Domino's Franchisee Association & 4584 \\
\hline Fitness Together & Fitness Together Master Franchisee Council & 401 \\
\hline Gold's Gym & Gold's Gym Franchisee Association & 465 \\
\hline Hardee's & Independent Hardee's Franchisee Association & 1224 \\
\hline Jackson Hewitt & Independent Council of Jackson Hewitt Franchisees, Inc. & 5778 \\
\hline KFC & Association of Kentucy Fried Chicken Franchisees & 4387 \\
\hline Meineke & Meineke Dealers Association & 772 \\
\hline Musak & International Planned Music Association & $60^{* *}$ \\
\hline Pizza Hut & International Pizza Hut Franchise Holders Association & 5084 \\
\hline Starwood Hotels & Association of Starwood Hotels Franchisees and Owners & $220^{*}$ \\
\hline Taco Bell & Franchise Management Advisory Council & 4279 \\
\hline Wendy's & Old Fashioned Franchisee Association & $4690^{*}$ \\
\hline Super 8 Motels & Owners 8 Association & 1887 \\
\hline Sylvan Learning & Sylvan Franchise Owners Association & $500^{* *}$ \\
\hline
\end{tabular}

All figures obtained from www.entrepreneur.com unless otherwise noted

*Figures estimated based on Franchise Times 2009 Top 200 Franchise Systems

**Figures obtained from interviews

Interviews averaging 53 minutes each were fully recorded and transcribed and field notes were written in-situ resulting in 780 pages of single spaced text. Archival material including open letters to franchisors, material on association websites and franchisee newsletters resulted in approximately 800 pages of published text. Taking an inductive approach to theory 
development, our data were analyzed in an iterative fashion to discern reoccurring patterns and themes. Researchers in the field of organizational behavior and sociology have used similar methods within the context of channels of distribution to engage in such inquiry and theory development (Bradach 1997; Pratt 2000). Preliminary open coding resulted in a set of codes and higher order themes that were iteratively re-defined as new data was collected and the authors discussed and reworked the data. This process occurred throughout data collection and themes were revised to parsimoniously reflect new emerging patterns while accommodating for conflicting data. Focused coding of the data was done utilizing Atlas.ti ${ }^{2}$, a well respected qualitative software package (Kozinets 2002). A theoretical journal was used to evaluate and incorporate extant literature to inform the interpretation of the data. Throughout this process regular discussions between the two authors helped clarify inconsistencies in the analysis while allowing each author to reflect on their interpretation of the data. As each author brought a unique perspective, one as member on a board, and the other experiencing associations in the field firsthand, these discussions helped to acknowledge potential biases that each researcher brought to their interpretation of the data.

\section{FINDINGS}

A scorpion needs to get across the river, and says to the frog, carry me across the river, and the frog says, you know, no, you'll sting me and I'll die. The Scorpion said, well no, once we get on the river, if I sting you, we'll both die; I'll drown. So the frog says, okay, and they get halfway across. The scorpion stings him and he says, why did you do that? He says, I'm a scorpion, it's what I do. Well, the scorpion's the franchisor and the frog's the franchisee. - Colin

Colin, in recounting the parable above, also stated that his association was blessed with a few board members that had been through the "war" and therefore would always be suspicious

\footnotetext{
${ }^{2}$ Some archival material was not loaded into Atlas Ti as electronic copies of text were unavailable - these data were coded by hand.
} 
of the franchisor. One such member, his legal counsel, initiates new board members by telling them this parable even though the relationship as it stands today between association and franchisor is highly collaborative. The franchisor in this case has fully recognized the association, has active dialogue with its leaders and has even offered to write mandatory membership in the association as a requirement in the franchise agreement.

The story above demonstrates the natural tensions between franchisee-franchisor cooperation and conflict that manifest in a franchisee association's organizational identity. Franchisee associations work to maintain solidarity among their membership by developing a distinct organizational identity separate from that of the franchisor while at the same time work with the franchisor to deliver instrumental benefits to their members. Association leaders

repeatedly expressed the challenges in managing these often conflicting tasks; being ever vigilant and ready to do battle by reminding themselves that the franchisor does not share their identity, while at the same time working constructively with the franchisor for the benefit of the system. In the following sections we present our findings related to these dialectical identity processes and detail how franchisee associations we studied work to manage them.

\section{Identity (In)Stability}

One factor emerged as fundamental to the formation and continuance of franchisee associations in the systems we studied; the transitory nature of the franchisor corporate identity juxtaposed against the stability of franchisee ownership in the system. We uncovered that corporate identity change on the part of the franchisor often acts as a catalyst for franchisee association formation while expectations of the franchisor's continued instability necessitate ongoing identity adaptation on the part of the association. Franchisee stability also plays an important role. Low turnover provides a stable environment for developing the relationships 
among group members that are necessary for strong identity construction (Littler and Salaman 1984).

Of the 19 unique associations studied, members in 15 systems pointed to changes in a franchisor's corporate identity (i.e. changes in perceived central and distinctive goals and values of the franchisor) as critical to understanding the evolution and maintenance of the association. Of those 15 systems, evidence from nine highlight the shift in ownership from the founder of the franchise to new ownership as a critical transition, a fundamental change in the corporate identity of the franchisor. Transitions such as the loss of a founder or merger or acquisition have long been recognized as critical junctures of identity change within an organization's identity lifecycle (Albert and Whetten 1985). As described by Tom, a 20 year franchisee and association board member whose wife has also been a franchisee for the past 30 years:

And just like in a family, you didn't always agree with “dad (the founder)," but the belief was that he truly was looking out for your best interests in the long term...you always believed he was just going to take care of you. Dad's always going to be there, always going to do the right thing. That's what you know. This company (private equity firm) comes in... it's a different world, and you're not prepared for that. - Tom

Even after the founder sells his interests to a third party the mere presence or tangential involvement of the founder provides some stability to the corporate identity of the franchisor. Though they may not have direct control over the operations of the system, as long as these iconic founders are still involved they provide a sense of security for franchisees that trust the system has retained continuity in its central values and has the best interest of franchisees at heart. However, once the founder leaves the system for good, this source of security is lost. This evolution is described by George, a 34 year franchisee:

In the end he (the founder) would always try to do what was right for people. And when the company was goin' through the very tough times he was very empathetic to the franchise system, and really felt bad about it. So that the culture over the years stayed 
there as long as he was around. So when he was gone it really, really was different. George

Thus, just as franchisees age and exit the system, founders too have a physical lifespan that leads to their termination as owners and leaders. However, unlike the franchisees in our data who often transferred ownership of their individual shops to the next generation in their families, system founders rarely do so. Instead, iconic founders such as Colonel Saunders of KFC and James McLamore and David Edgerton of Burger King often sell their system to a corporation or a private group of investors. The initial transition can be followed by a series of successive sales as demonstrated by KFC's ownership history. KFC first changed hands in 1964 when the Colonel sold the company to a private group of investors. Then between 1971 and 1997 it changed ownership four additional times ${ }^{3}$. Long time franchisees in the KFC system have witnessed 15 different presidents (Murry 2009) while Burger King franchisees have witnessed similar revolving corporate leadership with five different CEOs serving within a seven year period in the 1980s (Lowman and Jarratt 2009). Franchisees who have witnessed these kinds of changes within their own systems expressed a sense of insecurity coming from the perceived instability of the franchisor's corporate identity and highlighted these insecurities as fundamental to the formation and functioning of their franchisee associations.

Our data reveal that uncertainty also exists around how changes in the identity of the franchisor might impact the relationship between the franchisor and franchisee association itself. The relationship between franchisor and franchisee association typically is not institutionalized but rather depends to a great extent on the unique personal approach of the CEO or President of the franchise system. Thus, the relationship between franchisee association and franchisor can change overnight with the installation of a new corporate officer that is friendlier or more hostile

\footnotetext{
${ }^{3}$ Source KFC.com
} 
to the organization. Roger, a 37 year franchisee, when asked how he would characterize the relationship between association and the franchisor describes such anxiety:

The only thing I can say is that it probably changes from one president to the next. Some of them choose to work a little bit more closely with the association. The one we have today is not a big proponent...We've had relationships with presidents who have franchisees actively involved in what's going on and then we have the other ones, like we have today, that just head on down the road and you find out after it's been done what's been going on. So it creates anxiety especially when things are desolate. Roger

Such changes in leadership often require an association's identity to adapt in order to survive. If an association views itself as a constant opponent of the franchisor and the franchisor's corporate identity changes to embrace franchisees as partners, a failure to adapt can cause the association to dissolve due to lack of purpose. Likewise, if an association continues to define itself as a cooperative partner of the franchisor when its membership views the franchisor as a threat, the association will be viewed as failing to protect franchisee rights. Its members will see it as co-opted by the franchisor and not worthy of their support.

In juxtaposition to the instability of the franchisor corporate identity, franchisees in 14 of the 19 systems spoke of enduring or expected multi-generational commitments to the brand. Franchisees consistently noted that unlike corporate officers, they had a significant portion of their personal wealth and livelihood tied up in the franchise. They had nowhere else to turn to if it failed while corporate officers could simply move on to other companies. Jason, a 12 year franchisee and regional association president, explains such differences:

So we always talk about the fact that many of these corporate guys will come in and they'll make decisions; they're not gonna be around in 3, 5, 10, 15 years. But look at my father-in-law; he's celebrating his 43rd year. - Jason

The contrast between the enduring nature of franchisees when compared to the perceived transience of system ownership and management is a fundamental concept in understanding the functioning of franchisee associations. Stability on the part of franchisees provides the necessary 
environment to sustain a distinctive association identity that is continuous yet adaptive, and capable of resisting pressures towards static states of conflict and cooperation. Stability provides a communal structure and the shared moral responsibility necessary for developing strong ingroup distinctiveness. Such distinctiveness is vital for maintaining group boundaries in light of collaborative work with the franchisor. As evidenced in our data, multi-generational franchisees have a vested interest in the long term health of the system and are often highly attached to the brand and therefore work to temper in-group/out-group bias when it threatens the long term viability of the system. Stability among franchisees also encourages an active participatory membership allowing for social capital to develop that in turn encourages collective support for a leader's attempt to reframe their association's identity in light of changes in the franchisor's corporate identity. Such adaptation of the association's identity is crucial for its survival as shifts in the corporate identity of the franchisor threaten its distinctiveness.

\section{Managing Overly Cooperative Identity Framing}

When group members interact on a personal level and cooperate individually with those from identified out-groups, the strength of identification with one's own group is diminished and intergroup biases are reduced (Bettencourt et al. 1992; Brewer 1988) allowing each side to see the other's point of view. Such moves towards identity overlap can occur when a franchisee association's members and the franchisor work together on combined task forces that are tasked with working towards consensus on some set of issues. Patrick, a 29 year franchisee and association board member talks about such a cooperative work environment:

I get to work with this new president closely, being on this committee, I have a lot a confidence in him. I understand the corporate mentality and what drives, what motivates them. I think we're on a better track than what we've been in many years. - Patrick 
While such a cooperative environment may increase individual franchisees' influence in the system, a state of identity overlap is problematic for the franchisee association as failure to maintain a clear boundary between franchisor and the franchisee association blurs the distinction between the categories of "us" and "them". Decategorization is meaningful because the categorization process defining the association as "us" (i.e., the in-group) and the franchisor as “them" (i.e., the out-group) is central to the identification process (Gaertner et al. 2000). Without a clear distinction between the association and the franchisor, vigilance is hard to maintain leaving franchisees vulnerable to possible franchisor opportunism. The fear of slipping into this mode and being surprised by sudden changes in the franchisor's policies are what motivated the telling of the scorpion story to new association members.

Of the 14 franchisee associations that work cooperatively with the franchisor, members in eight systems expressed challenges in maintaining or affirming their independence and members of ten systems expressed challenges in maintaining membership rates in light of such cooperation. Over time continuing cooperative behavior pushes the independent association's identity ever closer to overlapping that of the franchisor. Using franchisee terminology, these associations are viewed as "drinking the Kool-Aid", taking the side of the franchisor and blurring the line between franchisor and franchisee association. FACs are often identified as these kinds of co-opted associations, with their leaders often thought of as working more for the benefit of the franchisor than for the franchisees.

In reaction to fears of co-optation engendered by such collaborative work environments, franchisee association leaders often work to reestablish lines of demarcation by defensively resisting the pull towards a wholly cooperative relationship. Barry, a former franchisee, who has 
worked in his franchise system for 18 years and is now the director of the franchisee association, describes such an instance:

You have to have that distance to maintain that independence. I have to tell you that as I have worked with these guys (the corporate franchisor) I've found myself more than one time, arguing their point. Arguing corporate's point and the board's like whoa, whoa, whoa, whoa, you know, we're not gonna do that. - Barry

In well established franchisee associations, we found that association leaders create formal structures to help reaffirm their distinctiveness from the franchisor. These structures often take the form of free spaces away from the franchisor where franchisees can openly interact without fear of retribution while establishing unique traditions that re-affirm their separation from the franchisor. These spaces include closed meetings open only to the franchisees, password protected web forums that encourage open and lively debate among franchisees, annual conferences separate from the franchisor, and association run magazines. Research on social movements points to the importance of these free spaces, defined as separate physical and psychological spaces beyond the control of those in power, in developing distinctive oppositional identities (Evans and Boyte 1992; Scott 1990; Polletta and Jasper 2001). Franchisee-only events at regional and national conferences, web forums and franchisee newsletters can reinforce in-group/out-group distinctions when used to remind members of the inherent adversarial nature of the franchisee-franchisor relationship. However, these spaces can also provide collaborative framing opportunities. For example, franchisors in some systems are invited guests at national and regional franchisee run conferences, and stories highlighting collaborative efforts between franchisee associations and franchisors may also appear in franchisee newsletters. Perhaps more importantly, once established, free spaces provide a ready platform for an association to collectively respond to changes in a franchisors' identity quickly, efficiently and forcefully. A newsletter's editorial, an association's president's speech at a 
conference or an open letter to the franchisor communicated through a website can often enable such adaptive framing.

The creation of free spaces often requires considerable financial and organizational resources and the continued independence of these spaces from the franchisor depends on a well funded association treasury. That independence is critical because these spaces are under continual risk of contamination from franchisor interference. Such a contamination is described by Henry, a former franchisee association president who has been with his system for 10 years:

But they (the franchisor) were so close that it smothered us. So just recently we called a meeting without corporate officers being part of it and our corporate office completely wigged out about it. I explained that this is what we have to do. We have to be able to talk freely and candidly. I don't have a problem after the meeting either involving you or letting you know what we talked about but I need the franchisees to be comfortable enough to just say how they feel. They can't do that with you there. - Henry

Another way to guard against identity overlap during times of a collaborative work environment is the establishment of war chests to fund future litigation against the franchisor. These war chests allow for rapid change from a cooperative to combative stance vis-à-vis the franchisor when change is viewed necessary by the association. Symbolically these war chests work to highlight the perception that franchisor opportunism is inevitable. During periods of cooperative behavior therefore, war chests help to reiterate the in-group/out-group distinctions and maintain a certain level of threat awareness. Colin describes such a threat:

We've got a strong association that is active and watching regularly and is vigilant. Then as a franchisor, you're gonna be much less likely to try to pull a fast one, 'cause you know the moment you do, we're gonna jump on you. - Colin

The social capital of an association's leaders, how these leaders are elected and appointed, and who they represent also help to affirm the autonomy of an association. In all the well established associations we studied, the evolution of the association eventually produced a freely elected body of leaders. Even though in some of these systems leadership may have 
started by self appointment to facilitate its establishment, well established associations move inevitably toward some variation of democratic regional representation. Regularly occurring election cycles work to legitimize the organization's leadership while assuring their independence from the franchisor. Franchisee leaders that are independently elected by a democratic process have significant social capital in the system. These individuals may be well respected long-term franchisees that are successful operators of their franchise units and capable of working effectively with the franchisor or individuals who have a history of protecting the interests of franchisees by challenging the power of the franchisor. Election cycles provide an avenue to reframe the identity of the organization, as newly elected leaders redefine their relationship with the franchisor. A potentially combative association identity can change overnight with the installation of newly elected association officers that are willing to work collaboratively with the franchisor. Representative elections also react dynamically to changes in association composition as new franchisees enter and reshape the identity of the organization helping to realign the organization's identity with its constituents.

Sometimes franchisors push to consolidate an existing FAC with an IndFA thus disrupting this political process. If the independent association is absorbed into a FAC, it often comes with restrictions including non-disclosure agreements that work to reduce the ability of franchisee leaders to effectively manage and communicate the association's identity. For these reasons our franchisee contacts repeatedly cautioned against actions that blurred the boundary between "us" and "them", even though these actions would increase collaboration. Tony, a 15 year franchisee, describes the concerns about his franchisee association merging with the FAC and points to the election process as critical in reaffirming its independence:

Most of the franchisees insist that we are to remain independent and the previous board members felt the same way. Yet the former FAC board members say that the franchisor 
has offered to give our association a significant amount of money to defray certain expenses and they think we should take it. Most franchisees and original board members seem to be of the opinion that we were self standing before this, and there is no good reason to take the cash from the franchisor. And once you start taking money, it creates a conflict... While we try to be as independent as we can, one thing that makes us less independent is that some of the board members came to the board by a different route. Once we've gone through a couple of election cycles that part should work itself out, but the thing that concerns me is the way those people think and will shape the future while they are still in office. - Tony

Though clear boundaries between franchisee and franchisor are essential for the creation and maintenance of an association, an association's existence also hinges on its ability to work cooperatively with the franchisor. Therefore, the ability to deftly manage the identity divide by managing the potential conflict that may arise from over exuberant in-group/out-group bias is also vital for the long term survival of associations as we discuss next.

\section{Managing Overly Combative Identity Framing}

Many franchisee associations are initially formed specifically to oppose the entity currently in control of the franchise system - be it founder, private equity group, or publicly traded company. In fact some begin as ad hoc groups formed to further litigation against that franchisor. Franchisees viewing the current franchisor as antithetical to their beliefs or self interest may form or join these associations to maximize their identity separation from the franchisor. At the individual level the literature describes such cognitive separation, a sense of separateness, as disidentification (Elsbach and Bhattacharya 2001). Such disidentification involves categorizing groups as rivals or enemies; however it does not imply identification with a group with an opposing meaning. You can therefore disidentify with the franchisor without identifying with the franchisee association that opposes them. Lacking a strong core identity for themselves, groups based on disidentification are defined exclusively by the force they oppose. Disidentification can be a strong uniting incentive during times of distress or perceived threat 
(See Stein 1976 for review), however after the conflict has passed (or lawsuit terminated) the group may collapse due to lack of its own unique identity. A recurrent theme discussed among franchisee association leaders and advocates was the transience of associations that had built an identity around a static state of conflict with the franchisor. Ultimately an association's long term survival must be based on franchisee identification with the association not their disidentification with the franchisor.

While relying on disidentification may not be successful in the long run, in the short run it is clear that associations benefit from periods of combative relations with the franchisor. In 14 of the 19 associations we studied members, reported that conflict with the franchisor was a crucial step in the development of their respective franchisee associations. Our sources also stated that during times of conflict membership in their groups increased, resulting in greater financial and operational capabilities. Perceived opportunistic acts by the franchisor often pushed formerly neutral franchisees to join an association perhaps by acting as a catalyst for "unfreezing” identification (Ashforth 1998) with the franchisor. Disidentification with the franchisor, therefore, may lay the groundwork for the eventual establishment of a more permanent franchisee association with its own distinctive identity or act as a mechanism to galvanize support to reenergize the association. Thus, in the short term, periods of strong disidentification and conflict with the franchisor can be useful to franchisee associations. As described in field notes taken at one franchisee conference, board members may frame their identity as combative to rally support and increase the power of the association in challenging the franchisor:

As pieces of information are leaked to franchisees and the story of the board and its disagreement with the franchisor unfolds, franchisee unity and disidentification with the franchisor is growing. Events and presentations build upon each other in creating a sense of unity among franchisees culminating with the town hall meeting where 
franchisees are asked to donate to the cause to send a message to the franchisor. I am even tempted to stick my hand in my pocket to "fight the fight of our lives". - Field Notes

Unfortunately, a static combative identity can quickly spiral out of control and threaten the operational efficiency of the system. However, in much the same way a well funded treasury can support an association's identity in opposition to the franchisor, it can also support the association's efforts to soften its combative identity. The hiring of lawyers, PR firms and industry experts can often quickly and credibly reframe the association's identity as more cooperative. Many mature franchisee associations (e.g., Dominos, Pizza Hut, Meineke) hire professional non-franchisee directors who can play the role of boundary spanners (Aldrich and Herker 1977) being supportive of franchisees but able to maintain a constructive collaborative dialogue with the franchisor. Such officers or directors may be seen as having neutral identities (Elsbach 1999), neither fully combative nor overly collaborative. When the franchisor is acting in a perceived negative fashion toward the franchisees therefore, the association may help finance the fight but when the threat has been removed, it can also act constructively by channeling association resources toward professional conflict resolution.

To further prevent an association's identity from becoming solely combative, association leaders sometimes work to sideline those members seen as detrimental to the relationship and institute policies that prevent one rogue franchisee from shifting the group to either identity extreme. In associations with democratic governance systems, this is often accomplished through term limits or regularly occurring election cycles. Robert, a 26 year franchisee and president of his regional association, in discussing a highly vocal franchisee named Lennie, describes such an issue:

Lennie is another vocal guy that's very sharp and that definitely has his opinion on things. I'd love for him to be president, because I think he'd be good, but he scares our association people too much. So they don't want him...I mean you can be vocal and 
strong you know, stand up for it. But, what you have to do is kind of a thin line. You don't want to alienate yourself from (the franchisor) so they won't talk to you at all. So it's kind of a thin line that you have to, have to walk. - Robert

Though some associations have online forums that allow for open discussion about the system and expressions of disidentification with the franchisor, franchisee association leaders often view these as potentially destructive to the association's relationship with the franchisor. Jeffrey, a 17 year franchisee and board member, describes such caution when dealing with open forums:

I can see that (an online forum) becoming kind of a bitch session for somebody to get somethin' off his chest and be very negative. I think that's somethin' we're gonna have to monitor and watch. - Jeffrey

Uncensored forums usually exist outside the legitimate boundaries of the association and are often hosted by third parties that are not officially sanctioned by the association. These sites accomplish the dual purposes of providing a forum for the fostering of a distinctive organizational identity while allowing the association to maintain its distance from communication that might be destructive to the delicate cooperative relationship it hopes to maintain with the franchisor.

\section{Building a Core Identity}

It is clear from our data that associations seek to establish identities that are strong enough to allow them to adapt to changes in their environment so that they can avoid being stuck in overly cooperative or overly combative relationships with the franchisor. In the literature on unions, the stability of the workforce and seniority of membership have been highlighted as critical variables for developing relationships among workers necessary for solidarity and collective union action (Clawson and Fantasia 1983; Littler and Salaman 1984). Such stability and seniority afford the group a rich repository of experiences and relationships with which to 
develop a continuous core identity. Then, when they need to switch from identities that are cooperative to combative or vice versa, they can do so without alienating their members. Evidence from 13 established associations in our data set point to the importance of three repositories for establishing a distinct organizational identity; the founder, brand, and other franchisees. The most firmly established associations in our data exhibit a strong central core of rituals, artifacts, and traditions that they draw from one or more of these repositories to develop and sustain a distinct organizational identity that contributes to its adaptability. These highly successful associations resemble communities and exhibit the established markers of community: consciousness of kind, shared rituals and traditions, and a clear sense of moral responsibility (Muñiz and O'Guinn 2001). Their identity is reproduced by their members through the use of storytelling and shared traditions, enabling a consciousness of kind or an awareness and identification with other members of the group to develop (McAlexander, Schouten, and Koenig 2002; Muñiz and O'Guinn 2001).

One source for developing a strong core is to adopt the founder as central to the meaning of the association even after the founder is no longer in control of the system. Such adoption facilitates two key functions. First, it provides identity consistency in contrast to perceived changes in system ownership and/or management. Secondly, it affords associations a rich set of symbols and artifacts that are malleable. Given the insecurity occasioned by changes in the identity of the franchisor, the role of the system founder in the mythology of these franchise systems cannot be overstated. In eight of the franchise associations, franchisees related the mythology of their systems by recalling an idealized founder and spoke of the good old days when the founder-franchisor cared for franchisees and looked out for the long-term interest of the system. Even in tough economic times these franchisees felt they could count on the founder to 
help franchisees "muck through". This characterization of the relationship was often in stark contrast to how franchisees characterized the current franchisor. The role of an iconic founder was often described as a father figure, with informants using this family metaphor when speaking of past relationships in the franchise system:

And so (the founder) was 'the dad.' And he had this dream and this belief, and he built the company. He really believed that if his franchisees were successful, then he would be successful. ... It was a family. -Tom

Susan, a franchisee for the past 42 years and past president of the association, used the ideals of the franchise founder to explain the strength of the association. She describes the association as a family, the symbolic archetype of community (Nisbet 1993). The family of franchisees, once personified in the system through the founder, is now embodied in the franchisee association:

Now (the Founder) didn't have any money. ... in those days people were very friendly and everything. They'd ask (the Founder) if he'd wanna stay with 'em, and he'd love it, 'cause otherwise he was sleeping in his car; he couldn't afford a motel. And, so, he then became friends and family with all these various people he was bringing into his family (The Franchise). He always thought about it as his family (The Franchise)...We (the Association) carried on this family tradition - Susan

Though the meanings associated with the franchise founder and the brands they built are often closely intertwined, associations also draw upon the brands themselves to construct their identity. Associations often appropriate the artifacts and rituals associated with the brand, becoming the legitimate keepers of the brand and its meanings. The brand name is almost always used in naming the association unless blocked by the franchisor on grounds of copyright infringement (e.g., Toasted Sub Franchisee Association). If successful, an association’s perceptual appropriation of the brand and its meanings can provide legitimacy to the association allowing access to the symbols, shared traditions, and stories of the brand. The important point here is that the brand and the franchisor (i.e., owner and manager of the system), although legally 
linked, are not the same entity. It was clear from our data that perceptions that the franchisor is failing to protect the brand or failing to be true to the brand meanings can allow the association to emphasize its own direct linkage to the brand and thus provide a distinctive identity for the association.

The third set of meanings that associations draw upon is derived from the franchisees themselves. Idolized franchisees and the values they uphold can provide powerful symbols of an association's identity. We found that such symbols are best maintained in mature systems where franchisees pass on franchise properties to family members that have grown up in the association, creating second and third generation franchisees. Franchisee associations, as enduring institutions within franchise systems, can provide a space for earlier generations to pass the legacy and stories forward to future generations. In such systems older generations are venerated and their past relations with the founder often afford them high status within the group. In addition, franchisees that have stood up to the franchisor in the past serve as combative symbols for the association to call upon when needed. Reference to these iconic franchisees and the social relationships among current franchisees therefore, both provide meaning helpful in establishing the association's identity. Christopher who elaborates on the "feeling", a moral responsibility to help fellow franchisees, tells such a story:

"I mean guys would drive from one city to another to help another guy open his store. Didn't know 'em, didn't have any vested interest in 'em, but they would just say, you know they knew, hey, there's a guy that's gettin' in the business, and, and let's go help him. So it's kinda been always that relationship of, of let's go help. You know, if you're in trouble, call, let me know what I can do to help; I'll be there...there'll be the guys right behind me supportin' me any way they can, any way that I need 'em to help. And, and that's kinda how our association has grown."-Christopher

It was clear from our data, however, that these elements of an association's identity so central in maintaining a core are difficult to sustain. Turnover among franchise properties or 
rapid expansion in the system results in an influx of new franchisees that fail to have history with the brand, founder and association. Such an influx may result in multiple subcultures of franchisees that vie for political power, creating divisions among the association. Such is described in an excerpt from field notes from an association conference.

This association is highly fragmented, the cultural core is being assaulted by new franchisees that have not been indoctrinated... as a result those that previously had cultural capital in the system no longer hold power as a new set of franchisees enter and are perceived by older franchisees as willing to toe the line for the opportunity for expansion in the system.-Field Notes

As long time franchisees exit the system, they siphon away the heritage of the group. Institutionalizing the artifacts, traditions, and rituals within the association therefore is critical. Annual national and regional conferences are fundamental to such a process. The proximity afforded by such retreats enables the enactment of rites and the use of artifacts in a way that establishes and reaffirms the distinctive and consistent identity of the organization (Trice and Beyer 1993). Use of such identity laden symbols also helps demarcate in-group out-group distinctions (Pratt and Rafaeli 1997; Elsbach 2003). In association gatherings we observed, founders were immortalized in scholarships, through auctions of their possessions, and by naming achievement awards in their honor. In reality many founders had contentious relations with their franchisees; however in revising the past, these associations are able to tap into a rich set of symbols relating to the brand and to recast stories about the founder to help build solidarity, often in opposition to the current franchisor. As highlighted by Gioia et al (2000), such revisionist history (Loftus 1980) often results in a mythology of the franchise system and of the association. If the mythology is compelling, as new franchisees enter the system they interact with long time members and are socialized into this interpretation of the past and the relationship between association and the founder. Former franchisees, too, are honored in golf tournaments and by awards in their names, facilitating discussions about the greatness of past 
franchisees in their battles with the franchisor. Association publications are also used as media for reaffirming the identity of the group and acting as efficient communicators of identity by highlighting those franchisees that uphold the values of the group. Such salient and attractive identity markers help promote behaviors that reaffirm the association's identity and transfer that identity to incoming franchisee members.

Associations that can utilize the set of traditions, rituals and artifacts embedded in the founder, brand, and fellow franchisees are particularly able to respond to changes in franchisor corporate identity. The symbols, rituals and artifacts help build a strong core identity that distinguishes the association and provides it the capability to shift its identity subtly towards a cooperative or combative identity frame as needed. During times of cooperation symbols of an association's struggle against the franchisor are utilized to draw a clear boundary between the franchisee association and franchisor. Rituals enacted during annual gatherings help highlight the group's solidarity. Myth-like stories revolving around the brand, founder and former franchisees provide malleable meaning that associations can adapt to meet current identity needs. When managed effectively, these symbols, rituals and artifacts can provide powerful support for the development of an association's distinctive and adaptive identity.

\section{IDENTITY ADAPTATION IN FRANCHISE ASSOCIATIONS}

Our findings suggest that organizational identity and its adaptation are integral factors in understanding a critical structure in franchise systems, the franchisee association. One of the primary reasons collectives fail is that the identity of the organization fails to line up with the perceived identity of its members (see Benford and Snow 2000 for review). Members begin to question whether the group still represents who they are and what they stand for in light of 
changes in the environment. A reframing of an organization's identity in light of shifts in the environment is thus crucial for the sustenance of organizations (Gioia, Schultz, and Corley 2000; Brown and Eisenhardt 1997; Benford and Snow 2000). In order to survive in the long run, franchisee associations must be viewed by their members as having an identity that is capable of being both cooperative and combative in its relationship to the franchisor. The association must be seen as able to work effectively with the franchisor while at the same time able to aggressively protect the interests of franchisees as the situation dictates.

The proffered answer, therefore, to our research question regarding the way that franchisee associations manage the inherent tension between conflict and cooperation in franchise systems is conceptualized in Figure 1, and reflects the central role of changes in the franchisor's corporate identity and franchisee association identity adaptation. The left side of the figure refers to the key factor in the requirement for identity adaptation, the instability of the franchisor's corporate identity. If the franchisor's identity were stable and predictable, the franchisee association could simply assume a static cooperative or combative identity. The franchisee association's environment however is inherently unstable. The right side of the figure refers to the association's ability to adapt. The association's adaptive capability is derived from financial resources, democratic governance, free spaces, rituals, traditions and artifacts, and franchisee stability. These sources of adaptive capability permit the creation of an identity for the association distinct enough to survive the changes in its environment occasioned by the franchisor's instability. 


\section{Figure 1: Organizational Identity Adaptation}

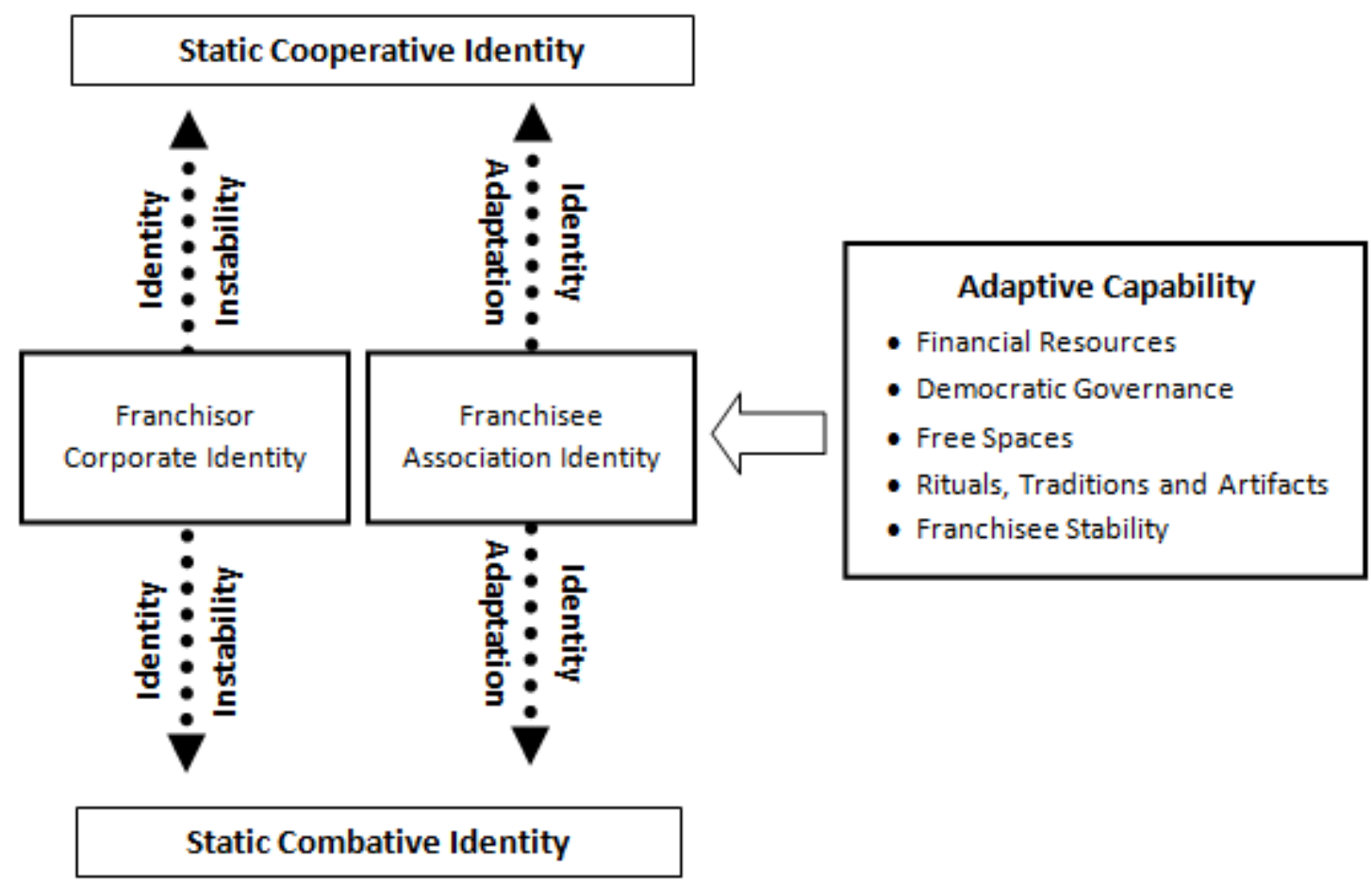

It is important to note several things about Figure 1. First, it describes a successful franchisee association, one that is able to sustain itself over time. Associations unable to adapt will be caught in a static state of cooperation or conflict and will either cease to represent the interests of franchisees or become irrelevant once the source of conflict is resolved. Second, the figure assumes the instability of the franchisor's corporate identity as reflected in our findings. Changes in franchisor ownership or management will produce changes in its dealings with the franchisees. It should be noted however that we have defined the franchisor's corporate identity as being viewed from outside. Franchisee perceptions of instability in the franchisor's identity reflect actual and anticipated change but can also be affected by the intentional framing of the franchisee association or through careful image management by the franchisor. The story of the 
scorpion represents an intentional framing of the franchisor's identity instability on the part of the leaders of the franchisee association.

Third, the suggested conceptualization is dynamic in the sense that adaptive capabilities possessed and continuously nurtured by the franchisee association provide the potential for the association to redefine itself in response to or in anticipation of changes in the franchisor's corporate identity. The association’s ability to adapt enables it to deliver both the system efficiencies derived from cooperation with the franchisor and protection from harmful franchisor actions to franchisees, should the need arise. The focus of successful franchisee associations, therefore, is on developing the financial capability to maintain its independence, creating and maintaining free spaces that permit unfettered communication, acquiring the rituals, traditions and artifacts that establish the basis for the feeling of community, and maintaining a sense of continuity within the association that can be juxtaposed with the perceived lack of stability of the franchisor (See Table 2). These capabilities create an identity for the association that is at the same time clear and distinct but also capable of reframing its relationship with the franchisor when required. It is an identity that is perceived by its members as an organization whose core values and goals center on representing the collective interests of franchisees within a highly dynamic environment. Franchisee associations that are able to maintain such an identity enjoy the continuing commitment of their members and productive working relationships with the franchisor. 
Table 2: Adaptive Capability

\begin{tabular}{|c|c|c|c|c|c|}
\hline & $\begin{array}{l}\text { Financial } \\
\text { Resources }\end{array}$ & $\begin{array}{l}\text { Democratic } \\
\text { Governance }\end{array}$ & "Free Spaces" & $\begin{array}{c}\text { Rituals, Traditions, } \\
\text { Artifacts }\end{array}$ & $\begin{array}{c}\text { Franchisee } \\
\text { Stability }\end{array}$ \\
\hline 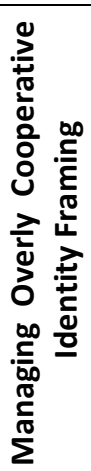 & $\begin{array}{l}\text { A well funded } \\
\text { association can } \\
\text { reaffirm boundaries } \\
\text { and credibly reiterate } \\
\text { in-group/out-group } \\
\text { distinctions though } \\
\text { the use of "War } \\
\text { Chests" that highlight } \\
\text { the inevitability of } \\
\text { franchisor } \\
\text { opportunism. }\end{array}$ & $\begin{array}{l}\text { Term limits or regularly } \\
\text { occurring election } \\
\text { cycles assist in } \\
\text { tempering static states } \\
\text { of cooperative identity } \\
\text { framing by reaffirming } \\
\text { the autonomy of the } \\
\text { association. }\end{array}$ & $\begin{array}{l}\text { Closed meetings, web } \\
\text { forums, annual } \\
\text { conferences, and } \\
\text { association run } \\
\text { magazines provide } \\
\text { opportunities to affirm } \\
\text { an association's } \\
\text { independence and to } \\
\text { develop a distinctive } \\
\text { oppositional identity. }\end{array}$ & $\begin{array}{l}\text { The enactment of rituals } \\
\text { and traditions and use of } \\
\text { symbols establishes and } \\
\text { reaffirms the distinctive } \\
\text { identity of the } \\
\text { organization while } \\
\text { demarcating in-group } \\
\text { out-group distinctions. }\end{array}$ & $\begin{array}{l}\text { Stability on the part of } \\
\text { the franchisees fosters } \\
\text { communal relations } \\
\text { among franchisees that } \\
\text { affirm their uniqueness } \\
\text { when juxtaposed against } \\
\text { franchisor corporate } \\
\text { identity instability. }\end{array}$ \\
\hline 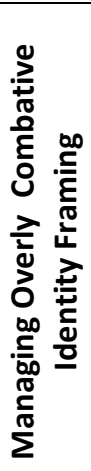 & $\begin{array}{l}\text { Financial resources } \\
\text { allow for the use of } \\
\text { professionals that can } \\
\text { act as boundary } \\
\text { spanners that can } \\
\text { temper static } \\
\text { combative identity } \\
\text { states. }\end{array}$ & $\begin{array}{l}\text { Term limits or regularly } \\
\text { occurring election } \\
\text { cycles assist in } \\
\text { tempering static states } \\
\text { of combative identity by } \\
\text { sidelining those seen as } \\
\text { detrimental to the } \\
\text { franchisee-franchisor } \\
\text { relationship. }\end{array}$ & $\begin{array}{l}\text { Uncensored free spaces } \\
\text { usually exist outside the } \\
\text { legitimate boundaries } \\
\text { of the association and } \\
\text { sanctioned free spaces } \\
\text { may allow for } \\
\text { cooperative identity } \\
\text { framing by including the } \\
\text { franchisor in the events. }\end{array}$ & $\begin{array}{l}\text { An adaptable mythology } \\
\text { of the association and } \\
\text { franchise system can be } \\
\text { used to temper static } \\
\text { combative identity states } \\
\text { by reminding members } \\
\text { of the importance of } \\
\text { cooperative relations for } \\
\text { the continued existence } \\
\text { of the system. }\end{array}$ & $\begin{array}{l}\text { Longtime members have } \\
\text { a vested interest in the } \\
\text { long term viability of the } \\
\text { system thus tempering } \\
\text { static combative identity } \\
\text { states. }\end{array}$ \\
\hline 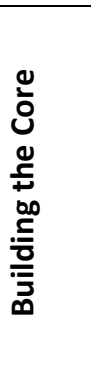 & $\begin{array}{l}\text { Financial } \\
\text { independence affords } \\
\text { the availability of free } \\
\text { spaces that provide } \\
\text { opportunities to } \\
\text { reaffirm a distinctive } \\
\text { identity while } \\
\text { fostering relationships } \\
\text { among franchisees. }\end{array}$ & $\begin{array}{l}\text { Election processes } \\
\text { affirm the social capital } \\
\text { and legitimacy of } \\
\text { leaders that can } \\
\text { credibly reframe the } \\
\text { association's identity. }\end{array}$ & $\begin{array}{l}\text { Free spaces allow } \\
\text { franchisees to openly } \\
\text { interact without fear of } \\
\text { retribution while } \\
\text { facilitating the } \\
\text { establishment and } \\
\text { transfer of unique } \\
\text { traditions, rituals and } \\
\text { symbols that re-affirm } \\
\text { their separation from } \\
\text { the franchisor. }\end{array}$ & $\begin{array}{l}\text { Appropriating the } \\
\text { meaning of the brand, } \\
\text { founder, and franchisees } \\
\text { provides a rich set of } \\
\text { rituals, traditions and } \\
\text { artifacts that support the } \\
\text { formation of a } \\
\text { community. }\end{array}$ & $\begin{array}{l}\text { A stable franchisee base } \\
\text { including multi- } \\
\text { generational franchisees } \\
\text { aid in the transfer and } \\
\text { institutionalization of } \\
\text { distinctive rituals, } \\
\text { traditions and artifacts } \\
\text { that help in development } \\
\text { of continuous identity. }\end{array}$ \\
\hline
\end{tabular}

Finally, while the conceptualization is agnostic with respect to the relative difficulty of changing toward a more cooperative or more combative identity frame, there was at least a suggestion in the data that change toward a more combative posture might be easier. It is much easier for franchisors to destroy trust than to earn it. The general level of suspicion that exists within many systems seems to support this idea. A franchisor's reputation for behavior destructive to the interests of its franchisees is very hard to change. On the other hand, a single 
salient opportunistic move on the part of a franchisor, theretofore viewed as cooperative, can have an abrupt effect on its corporate identity. Once a change in the franchisor's identity is perceived, it is also likely that some of the sources of adaptive capability may support a franchisee association's identity change in one direction more than another. For example, financial resources and free spaces may better support adaptation from cooperative to combative, while democratic governance and franchisee stability may be more suited to adaptation from combative to cooperative.

\section{DISCUSSION}

To fully understand franchising, it is important to understand the kinds of structures and institutions that play a significant role in the life of franchisees. In this paper we have argued that one such structure, the independent franchisee association, survives in a dynamically changing environment by carefully adapting its identity. The enduring nature of many of these organizations and their important role in the functioning of their franchise systems questions two implicit assumptions of franchise theory. First, the assumption that franchisees are lone economic and/or psychological actors that interact exclusively in a direct dyadic relationship with the franchisor is countered in our data. Rather we find that franchisee associations are rich repositories of inter-franchisee relationships. The financial incentives and personality traits that have been characterized as the full set of influences on the franchisee do not do justice to the complexity of social forces in play. Second, is the assumption of permanence on the part of the franchisor ${ }^{4}$. A recurring franchisee narrative views the franchisor as a perpetually unstable and

\footnotetext{
${ }^{4}$ Oxenfeldt and Kelly's (1968) assumption of stability of the identity of the franchisor can best be recognized by contrasting it with the lack of stability associated with the identity of the owner of a particular franchise unit. The ownership of particular franchises are seen as changing among franchisees and between franchisee and franchisor for a variety of reasons while the franchisor identity remains fixed in this analysis.
} 
unpredictable exchange partner while longtime franchisees and the associations they constitute view themselves as legitimate stewards of the brand. In light of our findings, the potential exists for a research program designed to uncover the full set of cultural, symbolic and social aspects embedded in franchising. Such a research program might well lead to increases in the predictive power of traditional economic models while improving management practice by enhancing standard incentive structures and governance mechanisms. To encourage such scholarship we offer three potentially fruitful avenues for future franchising research: (1) communal relationships (2) organizational identity, and (3) franchisee-franchisor identification.

Communal Relations: Our data are consistent with the idea that true communal relationships can exist within franchise systems and that these communities can form around strong attachments to a brand, a founder or fellow franchisees. Though significant empirical work on communities and subcultures within the B2C context exists (McAlexander, Schouten, and Koenig 2002; Muñiz and O'Guinn 2001; Schouten and McAlexander 1995; Muñiz and Schau 2005) work on communities within the B2B context has been scant. Research on franchising has tended to ignore the construct of community, even though descriptions of the franchise system as a family are commonplace. Unlike communal groups that form within the confined boundaries of the firm or among consumers who share a common brand affiliation, the unique tensions that exist within the franchise relationship provide an interesting setting to study the influence of communal relations on its members. Dunkin’ Donuts faced this kind of challenge in the 1980s when new franchisees who shared a common ethnic background looked to each other instead of the franchisor to determine their response to company initiatives (Kaufmann 1988). Franchisee based communities may also act as rich repositories of institutional knowledge. The rituals and traditions embodied in these organizations can be very 
useful in the creation, dissemination, and maintenance of firm specific intelligence. In addition, the normative pressures to conform to community standards are particularly relevant in light of the importance of uniformity in the success of franchising. Ethnographic work may shed light on the process of acculturating new members or achieving social capital in such groups as well as the factors involved in the inclusion or exclusion of the franchisor within the community.

Organizational identity: Concepts of brand identity (Aaker 1996; Keller 1993) and corporate identity have garnered significant interest among marketing scholars examining B2C relationships. Though organizational identity and its influence on franchise system management have not been considered important, our data suggests that many franchisors would be well served to carefully manage this aspect of the franchise relationship. Research exploring how some franchisors are successful in managing their identity during changes in leadership would provide critical insight into this potentially important process. Systems such as McDonalds ${ }^{5}$ or Chick-fil-A ${ }^{6}$ have purposefully managed their corporate identity by picking their senior leadership from within and by ensuring future generations of family leaders. Contrast this with the current CEOs of Dominos, Burger King, Blockbuster, and 7-Eleven, for example, where none had worked for the systems before being named to leadership positions in the company ${ }^{7}$. Developing leadership from within by promoting those with institutional knowledge and long term operational experience with the system, however, is difficult and may be especially difficult

\footnotetext{
${ }^{5}$ McDonalds has had a history of hiring from within with recent leadership in the corporation having long term relationships with the brand. The current CEO, Jim Skinner, has worked 38 years with the company and past CEOs Bell (30 years), Cautalupo (30 years), and Greenberg (21 years) had all worked significant portions of their lives with the company. In addition, the company strives hard to maintain its connection to the ideals of its founder Ray Kroc (Harris 2009)

${ }^{6}$ Chick-fil-A founder Truett Cathy remains CEO and chairman but has groomed his sons Dan and Donald from childhood to assume their current senior leadership positions in the company (Scott 2006).

${ }^{7}$ As described by the executive bios contained on their respective company websites
} 
for systems without company owned stores. Plural form organizations (i.e., systems with a mix of franchised and company owned stores) have the benefit of a depth of management experience at the store level providing potential for a life career with the brand. Future work examining the potential of different system structures in facilitating identity stability in light of changes in ownership or management would shed light on this crucial juncture in the lifecycle of a franchisor.

Franchisee-Franchisor Identification: As mentioned, marketing practitioners have recognized the potential benefits of promoting strong consumer identification by maintaining distinct attractive identities for their brands, companies and products. Identification is a "sense of oneness" with an organization where there is an emphasis on the collective over the individual and one's own identity overlaps with the organization's identity. Such identification is clearly present in a system like Chick-fil-A that selects operators with similar values to the founder and intensively socializes them to internalize the brand and closely identify with franchisor management (Reichheld 2001; Berry 2000). Much like relational norms facilitate the investment in firm specific assets (Heide and John 1992) or control opportunism (Brown, Dev, and Lee 2000) such identification between franchisee and franchisor may have salutary benefits including pro social behavior (O’Reilly III and Chatman 1986) and loyalty (Adler and Adler 1988). Franchising researchers, however, have not examined the potentially beneficial outcomes afforded by high levels of organizational identification on the part of the franchisee. Instead, franchising research has focused exclusively on governance through economic incentives via the carrot of residual profits and the stick of loss of ex post rents (Coughlan et al. 2006, 527) that are assumed to solve the inherent problems of the principle-agent relationship. The degree to which franchisee identification with the franchisor might serve to align their interests and thus impact 
franchisee behavior regarding such familiar issues as free riding or acceptance of franchisor initiatives are interesting research questions with important consequences for the management of such systems.

While opening up significant avenues for future inquiry, like other discovery-orientated research (Wells 1993), the study reported here has several limitations. Although the richness and depth of our experiences in the field provided significant insight into characteristics vital to understanding the formation and maintenance of franchisee associations, the sample was limited. Further work in additional systems using a variety of methods would be valuable in providing even greater variation across the different identity characteristics and permit an examination of their relative importance to different subgroups of franchisees. A typology of different identity types (i.e. communal, conservative, progressive) and their differential impact on franchisee identification would add greatly to our understanding of the franchisee-franchisor relationship.

Second, our unit of analysis was the organization (i.e. franchise association) rather than the individual franchisee. There is great potential for work looking at individual franchisees and their identification with the franchisor, brand, founder and franchisee based groups and the relationships that exist between these foci. The study of identification has the potential to uncover antecedents of important constructs such as intergroup bias and stereotyping leading to well established constructs such as conflict and trust. The study of multiple foci of identification may include questions such as: Can members of an association strongly identify with a franchisee association while simultaneously identifying with the franchisor? Are these two types of identification mutually exclusive?

Third, the majority of our interviewees were highly involved in their associations as long time franchisees with years of experience in the franchise system. Additional fieldwork is 
needed to explore other types of franchisees and their role in shaping these associations. Prior work in franchising has, for the most part, taken a one-dimensional approach to categorizing franchisees. Multi-unit operators, for example, have historically been defined as owning more than one unit. Our fieldwork reveals the potential for a much more nuanced social approach to categorization.

Lastly, our viewpoint was that of the franchisee association. Understanding franchisors' perspectives on their relationships with franchisee associations and how they work to manage franchisees in such organizations would provide added insight. Understanding how some franchisors successfully negotiate the transition from founder to outside ownership while maintaining legitimacy as brand stewards would be another significant contribution to practice.

\section{CONCLUSION}

This study represents the first step in a research program aimed at exploring the franchisee's relationship with the franchisor as embedded in a broader social structure. As revealed in our data, franchisees are not single economic actors simply reacting to economic incentive mechanisms but are social actors embedded within a complex set of interpersonal relationships. These inter-franchisee relationships have important implications for the management of franchise systems and for franchise research. The formalization of these relationships into persistent structures such as franchisee associations implies that there are additional entities within franchising that are in a position to interpret and frame franchisor incentives and monitoring behavior for their franchisee members. It also implies that in mature systems collective action may well be more likely than individual action when reacting to 
franchisor initiatives. These are realities that should be accounted for in our models of franchising.

A second finding is also worth reiterating. A maturing US franchise industry has resulted in an environment where an increasing number of franchisees work in franchise systems that are owned by large corporations or private equity groups with high levels of turnover among management. Many of the multi-generational franchisees we encountered in these systems perceive their relationship with the brand as more enduring than those of the current owner or management team. As system growth comes increasingly from within, this perception will only intensify. This narrative requires a reassessment of standard assumptions regarding the internal functioning of franchise systems and the actual roles, power and incentives of franchisor and franchisees within those systems. 


\section{References}

Aaker, David A. 1996. Building Strong Brands. Free Press New York.

Adler, Patricia A., and Peter Adler. 1988. Intense Loyalty in Organizations: A Case Study of College Athletics. Administrative Science Quarterly 33, no. 3: 401-417.

Albert, Stuart, Blake E. Ashforth, and Jane E. Dutton. 2000. Organizational Identity and Identification: Charting New Waters and Building New Bridges. Academy of Management Review 25, no. 1: 13-17.

Albert, Stuart, and David A. Whetten. 1985. Organizational Identity. In Organizational Identity; A Reader, ed. L.L. Cummings and B.M. Straw. Vol. 7. Greenwich CT: JAI Press.

Aldrich, Howard, and Diane Herker. 1977. Boundary Spanning Roles and Organization Structure. The Academy of Management Review 2, no. 2: 217-230.

Argyres, Nicholas S., and Julia Porter Liebeskind. 1999. Contractual Commitments, Bargaining Power, and Governance Inseparability: Incorporating History Into Transaction Cost Theory. The Academy of Management Review 24, no. 1: 49-63.

Ashforth, Blake E. 1998. Becoming: How Does the Process of Identification Unfold? In Identity in Organizations: Building Theory Through Conversations, ed. David A. Whetten and Paul C. Godfrey, 213:222. Thousand Oaks: Sage Publications.

Ashforth, Blake E., and Fred Mael. 1989. Social Identity Theory and the Organization. The Academy of Management Review 14, no. 1: 20-39.

Barkoff, Rupert, and Diane Green-Kelly. 2006. Selected Antitrust and Other Issues Involving Franchisee Associations and Purchasing Cooperatives. In . Proceedings of the American Bar Association 29th Annual Forum on Franchising.

Benford, RD, and DA Snow. 2000. Framing processes and social movements: An overview and assessment. Annual review of sociology 26, no. 1: 611-639.

Berry, Leonard L. 2000. Cultivating Service Brand Equity. Journal of the Academy of Marketing Science 28, no. 1: 128-137.

Bettencourt, B. Ann, Marilynn B. Brewer, Marian R. Croak, and Norman Miller. 1992. Cooperation and the Reduction of Intergroup Bias: the Role of Reward Structure and Social Orientation. Journal of Experimental Social Psychology 28, no. 4: 301-319.

Bhattacharya, C.B., and Sankar Sen. 2003. Consumer-Company Identification: A Framework for Understanding Consumers’ Relationships with Companies. Journal of Marketing 67, no. 2: 76-88.

Blair, Roger D., and Francine Lafontaine. 2005. The Economics of Franchising. Cambridge Univ Press.

Bradach, Jeffrey L. 1997. Using the Plural Form in the Management of Restaurant Chains. Administrative Science Quarterly: 276-303.

Brewer, Marilynn B. 1988. A Dual Process Model of Impression Formation. Advances in social cognition 1: 1-36.

Brickley, James A., and Frederick H. Dark. 1987. The Choice of Organizational Form: The Case of Franchising. Journal of Financial Economics 18, no. 2: 401-420.

Brown, Andrew D., and Ken Starkey. 2000. Organizational Identity and Learning: A Psychodynamic Perspective. Academy of Management Review: 102-120.

Brown, James R., Chekitan S. Dev, and Dong-Jin Lee. 2000. Managing Marketing Channel 
Opportunism: The Efficacy of Alternative Governance Mechanisms. The Journal of Marketing 64, no. 2 (April): 51-65.

Brown, Shona L., and Kathleen M. Eisenhardt. 1997. The Art of Continuous Change: Linking Complexity Theory and Time-Paced Evolution in Relentlessly Shifting Organizations. Administrative Science Quarterly: 1-34.

Burzych, Mark, Eric H. Karp, and Karen Boring Satterliee. 2004. Discriminatory Treatment of Franchisees. In . Proceedings of the American Bar Association 27th Annual Forum on Franchising.

Carney, Mick, and Eric Gedajlovic. 1991. Vertical Integration in Franchise Systems: Agency Theory and Resource Explanations. Strategic Management Journal 12, no. 8: 607-629.

Caves, Richard E., and William F. Murphy II. 1976. Franchising: Firms, markets, and intangible assets. Southern Economic Journal: 572-586.

Clawson, D, and R Fantasia. 1983. Beyond Burawoy: The Dialectics of Conflict and Consent on the Shop Floor. Theory and Society 12, no. 5: 671-680.

Cochet, Olivier, and Thomas Ehrmann. 2007. Preliminary Evidence on the Appointment of Institutional Solutions to Franchisor Moral Hazard-the Case of Franchisee Councils. Managerial and Decision Economics 28, no. 1: 41-55.

Coughlan, Anne T., Erin Anderson, Louis W. Stern, and Adel I. El-Ansary. 2006. Marketing Channels. 7th ed. Upper Saddle River, NJ: Prentice Hall.

Dant, Rajiv P. 2008. A Futuristic Research Agenda for the Field of Franchising. Journal of Small Business Management 46, no. 1: 91-98.

Dickey, Michael H. 2003. The Effect of Electronic Communication Among Franchisees on Franchisee Compliance. Journal of Marketing Channels 10, no. 3: 111-132.

Dutton, Jane E., and Janet M. Dukerich. 1991. Keeping an Eye on the Mirror: Image and Identity in Organizational Adaptation. Academy of Management Journal: 517-554.

Elsbach, Kimberly D. 1999. An Expanded Model of Organizational Identification. In Research in Organizational Behavior, ed. Robert I. Sutton and Barry M. Staw, 21:163-200. Stanford, CT: JAI Press.

- 2003. Relating Physical Environment to Self-Categorizations: Identity Threat and Affirmation in a Non-Territorial Office Space. Administrative Science Quarterly 48, no. 4: 622-654.

Elsbach, Kimberly D., and C.B. Bhattacharya. 2001. Defining Who You Are By What You're Not: Organizational Disidentification and The National Rifle Association. Organization Science 12, no. 4: 393-413.

Evans, Sara M., and Harry C. Boyte. 1992. Free Spaces: The Sources of Democratic Change in America. Chicago: University of Chicago Press.

Fullagar, Clive, and Julian Barling. 1991. Predictors and Outcomes of Different Patterns of Organizational and Union Loyalty. Journal of Occupational Psychology 64, no. 2: 129143.

Gaertner, Samuel L., John F. Dovidio, Brenda S. Banker, Missy Houlette, Kelly M. Johnson, and Elizabeth A. McGlynn. 2000. Reducing Intergroup Conflict: From Superordinate Goals to Decategorization, Recategorization, and Mutual Differentiation. Group Dynamics 4, no. 1: 98-114.

Galbraith, John Kenneth. 1954. Countervailing Power. The American Economic Review 44, no. 2: $1-6$.

George, Elizabeth, and Prithviraj Chattopadhyay. 2005. One Foot in Each Camp: the Dual 
Identification of Contract Workers. Administrative Science Quarterly 50, no. 1: 68-99.

Gioia, Dennis A., Majken Schultz, and Kevin G. Corley. 2000. Organizational Identity, Image, and Adaptive Instability. The Academy of Management Review 25, no. 1 (January): 6381.

Grünhagen, Marko, and Robert A. Mittelstaedt. 2002. Is Bigger Better?: The Anticipation of Scale Efficiencies and Decision Participation as Motivations for Aspiring Multi-Unit Franchisees. International Journal of Entrepreneurial Behaviour and Research 8, no. 3: 188-200.

Hammer, Tove H., and Robert Stern. 1986. A Yo-Yo Model of Union-Management Cooperation. Industrial and Labor Relations Review 39, no. 3: 337-349.

Harris, Patricia Sowell. 2009. None of Us is As Good As All of Us: How McDonald's Prospers by Embracing Inclusion and Diversity. Hoboken, NJ: Wiley.

Heide, Jan B., and George John. 1992. Do Norms Matter in Marketing Relationships? The Journal of Marketing 56, no. 2: 32-44.

Hing, Nerilee. 1995. Franchisee Satisfaction: Contributors and Consequences. Journal of Small Business Management 33, no. 2.

Jambulingam, Thani, and John R. Nevin. 1999. Influence of Franchisee Selection Criteria on Outcomes Desired by the Franchisor. Journal of Business Venturing 14, no. 4: 363-395.

Kalnins, Arturs, and Wilbur Chung. 2006. Social capital, geography, and survival: Gujarati immigrant entrepreneurs in the US lodging industry. Management Science 52, no. 2: 233.

Kaufmann, Patrick J. 1988. Dunkin' Donuts (E): 1988 Distribution Strategies. Harvard Business School Case \#9-589-017.

— 1996. The State of Research in Franchising. Franchising Research: An International Journal 1: 4-7.

Kaufmann, Patrick J., and Rajiv P. Dant. 1996. Multi-unit franchising: Growth and management issues. Journal of Business Venturing 11, no. 5: 343-358.

Keller, Kevin L. 1993. Conceptualizing, Measuring, and Managing Customer-Based Brand Equity. The Journal of Marketing 57, no. 1: 1-22.

Kozinets, Robert V. 2002. The Field Behind the Screen: Using Netnography for Marketing Research in Online Communities. Journal of Marketing Research 39, no. 1: 61-72.

Lawrence, Benjamin, and Patrick J. Kaufmann. 2010. Franchisee Associations: Strategic Focus or Response to Franchisor Opportunism. Journal of Marketing Channels 17, no. 2: 137155.

Littler, Craig R., and Graeme Salaman. 1984. Class at Work: the Design, Allocation \& Control of Jobs. Batsford, London.

Loftus, Elizabeth F. 1980. Memory. Reading, MA: Addison-Wesley.

Lowman, Elizabeth, and Ben Jarratt. 2009. Remembering Our Past: The History of Burger King Corporation. Flame: The Magazine of the National Franchisee Association.

McAlexander, James H., John W. Schouten, and Harold F. Koenig. 2002. Building Brand Community. Journal of Marketing 66, no. 1: 38-54.

Morrison, Kimberly A. 1997. How Franchise Job Satisfaction and Personality Affects Performance, Organizational Commitment, Franchisor Relations, and Intention to Remain. Journal of Small Business Management 35, no. 3.

Muñiz, Albert M Jr., and Thomas O'Guinn. 2001. Brand Community. Journal of Consumer Research 27, no. 4: 412.

Muñiz, Albert M. Jr., and Hope J. Schau. 2005. Religiosity in the Abandoned Apple Newton 
Brand Community. Journal of Consumer Research 31, no. 4: 737.

Murry, Lori. 2009. Leading the Association. AKFCF Quarterly.

Nisbet, Robert. 1993. The Sociological Tradition. New Brunswick, NJ: Transaction Pub.

O’Reilly III, Charles A., and Jennifer Chatman. 1986. Organizational Commitment and

Psychological Attachment: The Effects of Compliance, Identification, and Internalization on Prosocial Behavior. Journal of applied psychology 71, no. 3: 492-499.

Patton, Michael Q. 2001. Qualitative Research \& Evaluation Methods. Sage Publications.

Polletta, Francesca, and James M. Jasper. 2001. Collective Identity and Social Movements. Annual Review of Sociology 27, no. 1: 283-305.

Pratt, Michael G. 2000. The Good, the Bad, and the Ambivalent: Managing Identification Among Amway Distributors. Administrative Science Quarterly: 456-493.

Pratt, Michael G., and Anat Rafaeli. 1997. Organizational Dress as a Symbol of Multilayered Social Identities. Academy of Management Journal: 862-898.

Reichheld, Frederick F. 2001. Lead for Loyalty. Harvard Business Review 79, no. 7 (August): 76.

Reve, Torger, and Louis W. Stern. 1979. Interorganizational Relations in Marketing Channels. Academy of Management Review 4, no. 3: 405-416.

Rometsch, Markus, and Jörg Sydow. 2006. On Identities of Networks and Organizations-The Case of Franchising. Advances in Organizationn Studies 20: 19.

Rubin, Paul H. 1978. The Theory of the Firm and the Structure of the Franchise Contract. Journal of Law and Economics 21, no. 1: 223-233.

Schouten, John W., and James H. McAlexander. 1995. Subcultures of Consumption: An Ethnography of the New Bikers. Journal of Consumer Research 22, no. 1: 43.

Scott, Alan. 1990. Ideology and the New Social Movements. New York: Routledge.

Scott, Sheri Daye. 2006. Truett's Family Tree. QSR Magazine, May.

Scott, Susanne G., and Vicki R. Lane. 2000. A Stakeholder Approach to Organizational Identity. The Academy of Management Review 25, no. 1: 43-62.

Selden, Andrew C. 2000. Organization Design for Successful Franchising. Franchise Law Journal 20, no. 1: 21-32.

Spandorf, Rochelle B., and Rupert Barkoff. 2003. Close Encounters: Franchisee Associations and Councils. In . Proceedings of American Bar Association 26th Annual Forum on Franchising.

Stein, Arthur A. 1976. Conflict and Cohesion: A Review of the Literature. The Journal of Conflict Resolution 20, no. 1 (March): 143-172.

Tajfel, Henri, and John C. Turner. 1979. An Integrative Theory of Intergroup Conflict. In The Social Psychology of Group Relations, ed. G.A.S. Worchel, 33-47. Monterey, CA: Brooks-Cole.

Trice, Harrison M., and Janice M. Beyer. 1993. The Cultures of Work Organizations. Prentice Hall Englewood Cliffs, NJ.

Ullrich, Johannes, Jan Wieseke, Oliver Christ, Martin Schulze, and Rolf van Dick. 2007. The Identity-Matching Principle: Corporate and Organizational Identification in a Franchising System. British Journal of Management 18, no. 1: S29-S44.

Wells, William D. 1993. Discovery-Oriented Consumer Research. Journal of Consumer Research: 489-504. 


\section{Appendix 1: List of Interviewees}

\begin{tabular}{|c|c|c|}
\hline Name & Role & Yrs Exp. \\
\hline Angie & Board Member & 7 \\
\hline Barry & Association Director & 18 \\
\hline Charles & Former Board Member & 29 \\
\hline Christopher & Former Association President & 32 \\
\hline Colin & Association President & 25 \\
\hline Connie & Former Association President & 10 \\
\hline Danny & Former President of Franchise System & 35 \\
\hline Deborah & Association President & 7 \\
\hline Fred & Association Director & 35 \\
\hline George & Association Member & 34 \\
\hline Henry & Former Association President & 10 \\
\hline Jackie & Board Member & 3 \\
\hline James & Association President & 35 \\
\hline Jason & Regional Association President & 12 \\
\hline Jeffrey & Board Member & 17 \\
\hline Jennifer & Franchisee Non-Member & 7 \\
\hline John & Franchise Lawyer / Association Council & 25 \\
\hline Patrick & Board Member & 29 \\
\hline Richard & Association President & 28 \\
\hline Robert & Regional Association President & 26 \\
\hline Roger & Former Board Member & 37 \\
\hline Ryan & Board Member & 14 \\
\hline Sam & Association President & 17 \\
\hline Sarah & Association Member & 17 \\
\hline Steve & Board Member & 16 \\
\hline Susan & Former Association President & 42 \\
\hline Tania & Association Member & 11 \\
\hline Tom & Board Member & 20 \\
\hline Tony & Board Member & 15 \\
\hline Troy & Regional Association President & 13 \\
\hline Valerie & Franchisee Non-Member & 21 \\
\hline Wayne & Former Association President & 24 \\
\hline Walter & Franchise Lawyer / Association Council & 32 \\
\hline Zack & Association President & 16 \\
\hline
\end{tabular}




\section{Appendix 2a: Supplemental Data}

\section{Franchisor Instability}

When he came in (New Franchisor), he made it very clear that his philosophy was if you are planning on staying in the business for a long time, you are doing the wrong thing, you should be getting in, building up your business and selling it. That was his philosophy..he was after a quick profit. The problem is you can' $t$ start these stores and expect them to grow overnight, that's what he tried to force. - Zack

Those guys who are staffing key positions you know the corporate side of the business. They're looking to stake the next rung up the ladder and they're doing things that are going to perpetuate that and it's not necessarily the best thing for the brand or business.....it's unfortunate because too often they take the short term approach to a long term problem. And the franchisees...we're in it for the long haul unfortunately, in most cases we are. And we will take the longer term perspectives on things. Franchisor is more short term oriented and wants to see those immediate results... Every three or four years you have a new person (manager) coming in and changing direction and changing marketing strategy and changing numbers so consequently they get into the discounting program and your quality diminishes. - Roger

The relationship (between the association and franchisor) really depends on the management of the company, who the chief executive is and how they manage the relationship more than anything else. We went through a rough period during a time when we were making money the company brought in a new president....who ran the company like an MBA spreadsheet. - Wayne

I saw 8 presidents, and probably (Laugh) 10 or 11 VPs of marketing. So, part of the argument was guys, the decisions you all are making now, we have to live with. And, and I could very honestly look at the guy over the board, and said, you know what, you're probably not gonna be here next year; I'm still gonna be here. - Christopher

I was a franchisee for a franchisor that was publically traded and so the franchisees had 20 year licenses. But the CEO of the company had to report to the street every 90 days. Well it's very hard to be in sync with your goals and objectives when one's worried about surviving for 20 years and the other one's worried about what he's going to tell the street in 90 days. So a lot of short term, short sighted, sometimes reckless decisions are made in order to prop up sales, prop up profit. - Fred

Who knows who's gonna be sitting up there on the stage as the executive team 4 years from now..So, no, we don't wanna sign this thing and just, you know, carte blanche here you go. Charles

\section{Franchisee Stability}

We have a lot a franchisees that are hitting 50 years now with the brand. You know, it's, it's.... not uncommon to, to see, you know, 25, 30, 35, 40 year franchisees, and, and those are what we refer to as legacy. - Jason

Franchisees feel they have greater concern about the long term health of the business than the corporate guy who's passing through...And if you looked at the XXX system, there's very, very little turnover in that system. I mean the people that own it, own it for a long, long time. And there are people with probably hundreds of millions of dollars invested as opposed to a corporate guy who's collecting a paycheck. And that causes a very legitimate concern on the part of franchisees. You know, how do I know you have as much in this and as much concern for the future as I do? - Danny

We have some families that have owned franchises for 50 or more years. It is usually a very closed group that buys, for example the typical purchaser of a XXX franchise is another $\mathrm{XXX}$ franchisee or is a salesman or someone from the XXX community at large a son a nephew someone with familiarity and hooks into the system... They are often family businesses and these people have a long term view where they are building a business not just for themselves and for their current livelihood but to pass onto their children, hence they tend to be I think a little more conservative then the parent company.

Interviewer: How about the corporation? Has leadership in that been relatively stable?

No, there have been significant changes in the ownership of it, and over the last couple of years there have been revolving presidents and there has been significant changes in the ownership of the corporation over the years...During my tenure (32 years) the longest any CEO has been there is 5 years."- Walter

I wanted something to give to my kids. I mean down the road. My son would love to come in and take over my store. We've talked about that his whole life. It's not probably gonna happen, because we won't be around. That's the sad part. I bought into something as a long term investment, and this has been my career... This is something I can pass down to my kids...Y You know, this is a family business. It, it's sad that it's probably gonna go away. It makes me sad. - Tania 


\section{Appendix 2b: Supplemental Data}

\section{Managing Combative Identity}

What I'm rebuilding into the website is a way for there to be a productive conversation area and then an area to fix the complaint. So for those people that are feeling pretty good about things they don't need to read all the bitch moaning and groaning." - Fred

AVANTI was born from National Coalition dreams and franchisee editor Joe Saraceno's undying beliefs and determined efforts. In the second issue he cautioned the need for balance: "Actions which would tend to destroy the system make no more sense than building a roof over your head, while at the same time tearing down the walls and foundation designed to support it." - (excerpt from history of National Coalition of 7 Eleven Franchisees website www.ncasef.com)

Although we almost appear to be adversarial, you know, because we wanna protect franchisee rights and everything, I think more and more we look at everything as XXX Corporate are our partners. That's the approach that I know we take on our executive board, that they're our partners, because we're all heading in the same direction... Now there was a time when (franchisee association) was really perceived by (Corporate) as being very adversarial. And, I've never been one to wanna get involved in that. I, you know, I know who buttered my bread...Y You know, so it's a fine line. You know, you wanna protect your contract, you wanna protect your rights. But, you know, sometimes being arrogant or adversarial is not the way to accomplish that, and I don't like litigation.”- Jason

I'm like, "Oh my god! This would just be perfect! This is a guy (new director) that's just very organized, very well respected by the franchisees and by (the franchisor). Like I said, he was a golden boy as far as they (the franchisor) were concerned. So we thought, "Well, this is good. He'll get the respect he deserves. He can go in and talk to xxx one-on-one, CEO to CEO. This is perfect." - Tom

But there are a couple of Yahoo lists of (franchise) owners and, that is very active and very busy, and lots of people, lots a good conversation going on there. And, lots of mutual help and lots of supporting each other through the complaints and the frustrations. Sometimes the information from there gets through to the board, although the board tends to be resistant toward anything that comes from that group. - Jackie

The relationship that used to be nonexistent between DFA (IndFA) and DPLLC (corporate) is now open, respectful and starting to produce positive outcomes for our members. I know it is early on in our new relationship...but I am optimistic that we can continue the positive progress with the open communication we now have in place. - Ken Peebles CEO Dominos Franchiseee Association - The Voice Volume XII Issue IV

\section{Managing Cooperative Identity}

But now we're in a different place, and I hope we never get back to the place we're enemies, but if we do, we're much more prepared to, to fight than we ever would a been back then. I mean it took a lot to get organized, get people on board, and now we've got an organization in place that would be much more effective. And I think that becomes a deterrent. We've got a strong association that is active and watching regularly and is vigilant, then as a franchisor, you're gonna be much less likely to try to pull a fast one, 'cause you know the moment you do, we're gonna jump on you, and we're gonna publicize and we're gonna let people know. - Colin

The company seeing that it was going to happen anyhow, jumped in and offered to lend money to get it organized....but then they got a seat on the board of directors of the association which meant basically that they were inside. It was impossible at that point to discuss anything confidential between franchisees. - Wayne

It has been there's that feeling that the association is in the back pocket of the franchisor. We still have not really had a large issue that we've been on opposing sides... I think part of our problems as an association is that we haven't gone into battle with the franchisor so that hasn't really pulled us together as a group of all owners. It's like well everything is going fine so why should we bother joining the association. I think that may be a problem even though it's nice to have such a good working relationship with the franchisor it hasn't really pulled us together with a common cause.- Deborah

So you truly are independent and so you can fund yourself. You can put some money aside. It's always nice to be able to show the franchisor that you have 300,000 dollars put aside not because you expect anything bad to come up. But at least them know that if something really bad comes up you can fund a fight for a while. -Fred

O8A was formed in the spring of 2007, in an attempt to unite many loyal Super 8 franchisees that were concerned with issues in the Super 8 franchise system. We felt that the O8A was a necessary alternative to the Super 8 Franchise Advisory Board, since it did not adequately represent the majority of Super 8 franchisees and was made up of a limited number of franchisees, which served unlimited terms and were handpicked by Super 8 itself. - Excerpt from letter sent to John Valletta, president of Super 8 Motels, Inc., Jay Patel, head of the Owners 8 Association

More important than anything else in the franchise association world is a huge defense fund. And I look at it like this: nuclear warheads -- we have them, and I hope to god we never have to use them." - Tom 


\section{Appendix 2c: Supplemental Data}

\section{Building the Core}

Keeping the legacy of Dave Thomas alive is very important to OFFA. Dave embodied the virtue of humility which reverberated throughout the entire system. At our November 6th meeting in Dublin, Ohio, we took another step designed to keep Dave's fundamental values alive in the system. The Board of Directors along with membership worked to revise the OFFA Mission Statement to purposely imbue our independent association of franchisees with the heritage of Dave Thomas. The OFFA Mission Statement now reads: Our mission is to give Wendy's franchisees an independent, credible voice in the Wendy's system for the purpose of preserving the values Dave Thomas instilled in us and enhancing our members' investment and profitability. In addition, our Vision Statement now says: "We are the steward's of Dave's legacy." Wendy's is about the passion we all have for this system and the family of Wendy's franchisees. We miss the culture that Dave instilled in the organization and we miss the profitability. - Joe Johal President OFFA (Wendy's IndFA) OFFA Newletter - Volume 1 Number 1

One of the things (the founder) was really strong on was, was maintaining really strong franchise relations. There was a lot a respect, and you know mutual respect, and it was felt out there. And I was on the corporate side at that time. And it was part of our job, it was, you know, you know, you know to make sure you, the franchisees are payin' us $4 \%$, make sure we give 'em the service that they need. - George

It was the feeling the (founder) had. The feeling he exuded. And, we all... developed this, there's a word I'm tryin' to think of, this... uh... pattern, you know... it's (the association) is closer than I am to most any family really. So, it, it's, and I attribute it to (the founders) uniqueness. It's a culture, that's the word I was tryin' to think of ..there's a culture there that... I... don't think you'll find with any other franchise group. Susan

He (the founder) had stepped away from the company for a while; he stepped back in and said, "Look," you know, "my franchisees are having a really rough time. We're all in this together." His motto was kind of, "Pull on your boots -- we're all going to muck through this. He made it so that no one flew first class, including himself. You know, he drove a -- I think it's a 1970 Suburban around town, a, you know, beat-up -- you know, just a very down-to-earth man. The money wasn't really what he was there for. So he came back into the company, and the company kind of rallied back together. Tom

\section{Building the Core}

IMAGINE TAKING A U.S. HISTORY COURSE TAUGHT BY THE MEN AND WOMEN WHO ACTUALLY MADE THE HISTORY, people like George Washington, Abraham Lincoln, Amelia Earhart, Franklin Roosevelt and Martin Luther King. That's more or less what transpired when a panel of KFC franchisee forefathers (and oneforemother) delivered a two-hour history lesson at the AKFCFannual meeting in Las Vegas in 2005, only instead of U.S. history, the subject was the history of the AKFCF... Recalling philosopher George Santayana who said, "those who do not remember the past are condemned to repeat it" Schlutz said in his introductory remarks, "The AKFCF has a rich history that will be a critical key to our future. Preserving our history is the key to our future success.” - AKFCF Quarterly - Summer 2009 (Special Anniversary Edition)

In recognizing the accomplishments of the system the current president of the system recognizes the contribution of franchisees to the system using the following phrases "We are (the brand)," A key theme of the president's presentation is the idea of family and the idea that (the founder) is head of the this household. As with other families there is tension between change and keeping the heritage of the brand and founder exemplified in statements such as "the family is having tough times” and asking “what would (the founder) do?”... They bring board members up on stage and the lights dim low as the board members face the screen where the association creed is displayed and is played over the loud speakers. - Field Notes

For those of us who were privileged to work with BURGER KING's founding father, Jim McLamor, you knew that he and his partner, David Edgerton, always respected franchisees as independent business owners and proud stewards of a proud brand...I think it's important for us to remember our heritage as we strive to build a better brand... On behalf of your NFA officers, directors and members, I believe that franchisees will continue to be the same voice of reason and responsible stewards of our brand. We need to remain diligent as 'Keepers of the Flame' as we continue to move our brand forward.

William A Harloe - Chairman NFA (Burger King IndFA) - Flame Issue 12009

The, you know, I, I don't think there's a, a franchisee that doesn't have the highest and utmost respect for (the founder). For his philosophy, and for what he did. You know, when we have meetings and everything, we always honor (the founder). - Jason 


\section{Appendix 3: Coding Guide}

Code Family: Expressions of identity: Expressions of association identity.

- Id with Brand: Indications that the associations identity is built around brand meanings.

o Discussions of the brand and its meanings

o Discussions of brand stewardship/maintaining the brand for future generations

0 Using the brand name/ image and meanings in association literature and communications

- Id with Founder: Indications that the associations identity is built around the founder.

o Discussions of the founder and his beliefs

o Storytelling about the founder and their interactions with the association and its members

o Using the founders name/image and meanings in association literature and communications

- Id with Franchisees: Indications that the associations identity is built around franchisees.

o Discussion of association history (founders, visionaries, inaugural presidents)

o Discussions regarding key milestones (first gathering, battles) and the franchisees involved

o Use of past franchisee names in award ceremonies, gatherings and scholarships

- Dis Id with Franchisor: Indications that the associations identity is built around disidentification with franchisor.

o Describing the franchisor as enemy

o Describing the mission of the association as fighting the franchisor

o Highlighting the franchisor as different then the association

Code Family: Identity Stability: Expressions related to the relative stability/instability of franchisee/franchisor.

- $\quad$ Stable Franchisee: Expressions of franchisee stability to include:

o Long term franchisee commitment to the brand

o Franchisees as multi-generational family businesses

o Long term relations among franchisees and the association

- $\quad$ Stable Franchisor: Expressions of franchisor stability to include:

o Founder involvement in the system

o Stability in franchisor management

o Stability in franchisor ownership

o Stability in franchisor policies towards franchisees/association

o Long term relations between franchisee and franchisor

- Unstable Franchisee: Expressions of franchisee instability to include:

o Inflows of new franchisees / outflows of old

o Frequent changes in franchisee association leadership (not term based)

0 Changes in franchisee composition

- Unstable Franchisor: Expressions of franchisor instability to include:

o Changes in franchisor management

o Changes in system ownership

o Changes in franchisor policy towards franchisee/ franchisee association

o Perceived future changes of franchisor identity 
Code Family: Identity Management: Structural characteristics of an association that work to manage the identity of the organization. To include leadership structure, political process, interactions with the franchisor/management, communications with franchisees and franchisee gatherings.

- Managing Combative Identity :Characteristics related to managing combative identity.

o Franchisee leadership composition (former franchisor employee, non-franchisee professional director, hiring of outside mediator)

o Expressions by leadership of working together for common goal

o Expressions of controlling dissent (controlling web forums, sidelining troublemakers)

o Changes in leadership to improve relationship with franchisor

- $\quad$ Managing Cooperative Identity :Characteristics related to managing cooperative identity.

o Democratic election processes

o Maintaining separation from the franchisor (cognitive/physical) /"A fine line"

o War Chests

o Expressions of future litigation and potential conflict with franchisor

o Communications with franchisees indicated transparency of board

o Regional and national franchisee only gatherings

o Franchisee run newsletters/web forums

Code Family: Core Elements : Evidence of fundamental elements of core identity. Including symbols, traditions, history, and rituals embodied in the association.

- Symbols/Artifacts: Use of symbols/artifacts such as those of the brand, founder and historical franchisees in association gatherings and communications.

- Traditions: Evidence of the enactment of traditions in franchise gatherings and communications. To include annual awards, sporting events and presentations. Support of particular charities related to the brand or the association.

- History: Evidence of storytelling surrounding the brand, association, and members. Celebration of historical figures and events in the system to include "wars" with the franchisor, milestones for the association and brand.

- $\quad$ Rituals: Evidence of the performance of symbolically rich scripted performances surrounding the brand and association.

Family Code: Franchisee Association Descriptions: Descriptions of the association as family, community or resource.

- Family: Description of the association as family.

0 Association members described as being part of a family members

o Association members described as brotherhood/sisterhood

o Founders described as patriarchs or matriarchs

- Community: Description of association as community.

o Consciousness of kind

o Moral responsibility

o Shared rituals and traditions

o Evidence of in-group/out-group distinction.

- Resource: Description of association as resource.

o Focus on economic benefit/cost of membership

o Expressions of getting your money's worth 